\title{
Determination of Methylumbelliferyl-N-acetylneuraminic Acid Sialidase for Clinical Purposes
}

\author{
By W. R. Den Tandt \\ Medical Biochemistry, Antwerp University Medical School, Wilrijk, Belgium and
}

\section{R. Brossmer}

Institut für Biochemie II, Universität Heidelberg, Federal Republic of Germany

(Received March 3/October 27, 1983)

Summary: In order to determine optimal conditions for the clinical application of leukocyte acid sialidase determination, we have studied some characteristics of the enzyme giving attention more specifically to the enzyme's thermolability and the influence of potential effectors.

The enzyme has a $\mathrm{pH}$ optimum around 4 and a $K_{\mathrm{m}}$ value of $0.25 \mathrm{mmol} \cdot 1^{-1}$.

A decrease of activity is observed when the enzyme is measured in leukocytes isolated from total blood or leukocytes containing plasma kept for several hours at room temperature. On the other hand, in a leukocyte homogenate, the enzyme is stable at $0^{\circ} \mathrm{C}$ for 8 hours although pronounced thermolability is observed at 23 and $37^{\circ} \mathrm{C}$ and total inactivation occurs after 10 minutes at $50^{\circ} \mathrm{C}$. The addition of albumin to the homogenate partially protects the enzyme. Residual activities of $40 \%$ and $50 \%$ were measured in leukocytes and leukocyte homogenates frozen during 2 months at $-20^{\circ} \mathrm{C}$.

A marked inhibition was obtained by Triton X-100, sodium taurocholate, and methoxyphenyl-N-acetylneuraminic acid.

Immediate isolation of the leukocytes after the blood drawing and subsequent homogenization at $0{ }^{\circ} \mathrm{C}$ of a dense pellet make it possible to achieve enzyme linearity and reproducible results.

\section{Bestimmung der Methylumbelliferyl-N-acetylneuraminsäure spaltenden sauren Sialidase für klinische Zwecke}

Zusammenfassung: Zur Festlegung optimaler Bedingungen für die klinische Anwendung der Bestimmung von saurer Sialidase der Leukocyten haben wir einige Eigenschaften des Enzyms untersucht und dabei besonders auf die Thermolabilität und den Einfluß möglicher Effektoren geachtet.

Däs Enzym hat sein pH-Optimum bei pH 4 und eine Michaelis-Konstante von $0,25 \mathrm{mmol} \cdot \mathrm{l}^{-1}$.

Wir beobachteten einen Aktivitätsver lust, wenn das Enzym in Leukocyten gemessen wurde, die aus Vollblut isoliert worden waren oder in Plasma für mehrere Stunden bei Raumtemperatur gehalten wurden. Dagegen ist das Enzym in einem Leukocytenhomogenat für 8 Stunden bei $0^{\circ} \mathrm{C}$ stabil, während eine ausgeprägte Thermolabilität bei 23 und $37^{\circ} \mathrm{C}$ sowie völlige Inaktivierung nach 10 Minuten bei $50^{\circ} \mathrm{C}$ beobachtet wird. Zugabe von Albumin zum Homogenat schützt das Enzym teilweise. Restaktivitäten von $40 \%$ und $50 \%$ wurden in Leukocyten bzw. Leukocytenhomogenat gemessen, die während 2 Monaten bei $-20^{\circ} \mathrm{C}$ aufbewahrt wurden.

Eine deutliche. Hemmung wurde mit Triton X-100, Natrium-Taurocholat und Methoxyphenyl-N-acetylneuraminsäure erhalten.

Unmittelbare Isolierung der Leukocyten nach der Blutentnahme und nachfolgende Homogenisierung bei hoher Zelldichte und $0^{\circ} \mathrm{C}$ lassen Linearität und reproduzierbare Ergebnisse erreichen. 


\section{Introduction}

Methylumbelliferyl- $\mathrm{N}$-acetyl- $\alpha-D$-neuraminic acid, a fluorimetric substrate for sialidase (EC 3.2.1.18) was synthesized by Potier et al. (1), Werner \& O'Brien (2), and Eschenfelder (3).

Since the enzyme cannot be measured in plasma (results not shown), we have studied the leukocyte enzyme characteristics in order to find optimal conditions for the determination. The assay of this enzyme is useful for fast biochemical investigation of suspected cases of sialidosis, a disease characterized by a sialidase deficiency.

The effect on sialidase of the time lapse between blood sampling and isolation of the leukocytes was examined and attention was focused on enzyme stability at different temperatures between $-20^{\circ} \mathrm{C}$ and $+50^{\circ} \mathrm{C}$ and the influence of albumin and detergents.

Since the fluorescent end product of the reaction is measured by simple alkalization, this method has permitted the investigation of possible inhibition by other substances containing terminal sialic acid (and therefore used in colorimetric sialidase determinations), without colour development interference.

\section{Materials and Methods}

Chemicals

Methylumbelliferyl-N-acetyl- $\alpha-D$-neuraminic accid was prepared by Mrs. $U$. Rose, Heidelberg. Sodium acetate, sodium carbonate, sodium hydrogencarbonate, potassium phosphate and Triton $\mathrm{X}$ 100 were obtained from Merck, Darmstadt, W. Germany. Sialyllactose, fetuin III and IV, mucin, colominic acid, albumin and sodium taurocholate were purchased from Sigma, St. Louis, MO, USA. Methoxyphenyl-N-acetylneuraminic acid was a gift from the National Institute of Allergy and Infectious Diseases, NIH, Bethesda, MD, USA.

Isolation of leukocytes and homogenate preparation

Leukocytes were isolated from $20 \mathrm{ml}$ of heparinized blood by sedimentation (generally between 1 and 3 hours) at room temperature followed by two washings with isotonic saline. In general, contamination by red blood cells was minimal and lysis of the remaining red blood cells was obtained by adding $0.3 \mathrm{ml}$ of distilled water for 20 seconds and restoring the normotonicity immediately by adding a 30 times greater volume of isotonic saline. Cold bidistilled water $(0.5 \mathrm{ml})$ was added to the pellet and homogenization of the cells was achieved during exactly 30 seconds in a Potter-Elvejehm vessel kept in ice. In this procedure, no estimation of cellular destruction or cell count was performed, because activity was expressed per $\mathrm{mg}$ protein. The extract was used immediately for measuring the enzyme catalytic activity unless otherwise stated.

In other experiments, we tested the effect of mechanical forces by homogenizing a pellet during different times from short periods up to 5 minutes, taking repeat samples for catalytic activity measurement. Pipettable homogenates could be obtained after a 5 second homogenization period and the enzyme activity in this homogenate was therefore used as the $100 \%$ reference. The homogenization was then continued while taking repeat homogenate samples. With increasing times of homogenization pipetting became easier. An arbitrary period of $\mathbf{3 0}$ seconds was therefore established as the standard method of homogenate preparation.

\section{Enzyme determination}

Protein was determined according to Lowry et al. (4). Acid sialidase was measured as follows: In small glas tubes (internal diameter $0.3 \mathrm{~cm}$, length $3 \mathrm{~cm}$ ) $10 \mu \mathrm{l}$ of leukocyte homogenate together with $2 \mu \mathrm{l}$ of $1 \mathrm{~mol} \cdot \mathrm{l}^{-1}$ sodium acetate buffer $\mathrm{pH} 4$ and $10 \mu \mathrm{l}$ of 0.2 $\mathrm{mmol} \cdot 1^{-1}$ substrate (total volume $22 \mu \mathrm{l}$ ) were incubated at $37^{\circ} \mathrm{C}$ for 15 and $30 \mathrm{~min}$. Substrate blanks with buffer were incubated separately. The reaction was stopped with $0.250 \mathrm{ml}$ of $0.5 \mathrm{~mol} \cdot \mathrm{I}^{-1}$ sodium carbonate-hydrogen carbonate $\mathrm{pH} 10.7$ and homogenate was added to the blanks. The fluorescence was read in the high sensitivity sample holder of the Turner fluorimeter using excitation and emission wavelengths of 360 and $460 \mathrm{~nm}$ respectively.

The $\mathrm{pH}$ activity curve was determined by the routine test, using 1 mol $\cdot 1^{-1}$ sodium acetate $\mathrm{pH} 3-6$, and $1 \mathrm{~mol} \cdot 1^{-1}$ potassium phosphate $\mathrm{pH} 6.5$ and 7.

For the thermolability studies, either total blood or plasma containing the leukocytes was kept at room temperature, and sialidase was determined at different times up to 8 hours after the blood drawing, without and with albumin (final concentration 5 $\mathrm{g} / \mathrm{l})$. In a second set of experiments, leukocyte homogenates were kept at different temperatures $\left(0,23,37,50^{\circ} \mathrm{C}\right)$ for up to 8 hours and the enzyme activity measured at regular time intervals. In another series of experiments, either leukocyte pellets or homogenates were kept frozen at $-20^{\circ} \mathrm{C}$. Therefore either intact leukocytes were frozen under a small amount of physiological saline or the leukocyte homogenate was transferred to small stoppered glass tubes immediately after homogenization and stored at $-20^{\circ} \mathrm{C}$. The homogenate was unfrozen only once at the time of the enzyme determination which was carried out in the same tube.

For the inhibition studies, graded amounts of potential inhibitors (maximal final test concentration in parentheses) such as sialyllactose $(0.5 \mathrm{~g} / \mathrm{l})$, fetuin III and IV, mucin, colominic acid (each 1.15 $\mathrm{g} / \mathrm{l})$, Triton $\mathrm{X}-100(2 \mathrm{~g} / 1)$, Na-taurocholate $(10 \mathrm{~g} / \mathrm{l})$ and methoxyphenyl- $\mathrm{N}$-acetylneuraminic acid $(6 \mathrm{~g} / \mathrm{l})$ were added to the incubation medium.

\section{Results}

The $\mathrm{pH}$ activity curve shows an optimum at 4 (fig. $1)$. The protein concentration of the homogenates varied between 3 and $17.6 \mathrm{~g} / 1$. For the thermolability studies, the protein concentration was $10 \mathrm{~g} / \mathrm{l}$.

Residual activity of sialidase was unchanged after an homogenization period up to 30 seconds. After 1,2, 3 and 5 minutes, the activity dropped to $91,73,60$ and $0 \%$ respectively.

The use of a dense leukocyte homogenate allows short incubation times of 15 and 30 minutes so that strict reaction linearity and minimal non-enzymatic substrate hydrolysis was obtained.

Using 10 samples, normal catalytic activities between 1.10 and $6.50 \mathrm{nmol}$ of substrate hydrolysed per hour and per mg protein (mean value of 2.23) were obtained with a coefficient of variation within $10 \%$. 




Fig. 1. pH activity curve of a leukocyte homogenate. The standard method was used with $1 \mathrm{~mol} \cdot 1^{-1}$ sodium acetate buffer $\mathrm{pH} 3-6$ and $1 \mathrm{~mol} \cdot \mathrm{1}^{-1}$ potassium phosphate buffer pH 6.5 and 7.

Using substrate concentrations between 0.012 and $2.4 \mathrm{mmol} \cdot 1^{-1}$, a $K_{\mathrm{m}}$ value of $0.25 \mathrm{mmol} \cdot 1^{-1}$ was found. It should be remarked however that a much lower $K_{\mathrm{m}}$ value in the order of $0.052 \mathrm{mmol} \cdot \mathrm{l}^{-1} \mathrm{can}$ be obtained when other substrate concentrations (between 0.003 and $0.12 \mathrm{mmol} \cdot \mathrm{1}^{-1}$ ) are used (5) ${ }^{1}$ ).

Either total blood or leukocyte containing plasma was kept at $23^{\circ} \mathrm{C}$ and the catalytic activity of sialidase determined at fixed intervals of $1,2,4$ and 8 hours. No difference was observed between plasma or total blood, and a time-dependent loss of activity of the supposedly intact intralysosomal sialidase was observed. After 2 and 8 hours, a residual catalytic activity of 72 and $50 \%$ respectively remained (total number of 8 samples assayed).

In a second series of experiments on the influence of temperature, we noted that after 8 hours at $0{ }^{\circ} \mathrm{C}$, there is a recuperation of $90 \%$ of the enzyme in leukocyte homogenates, but the residual catalytic activity dropped to about $50 \%$ after the same period at $23^{\circ} \mathrm{C}$ and the total enzyme activity was lost after 4 hours at $37^{\circ} \mathrm{C}$ and $10 \mathrm{~min}$ at $50^{\circ} \mathrm{C}$. When we added albumin (final concentration of $5 \mathrm{~g} / \mathrm{l}$ ) to the homogenate there was marked enzyme protection with retardation of inactivation at 23 and $37^{\circ} \mathrm{C}$ (fig. 2).

After an 8 weeks storage period of pellets at $-20^{\circ} \mathrm{C}$, the residual activity was approximately $40 \%$. On the other hand, when determinations were carried out on homogenates kept under the same conditions, the mean value was $50 \%$.

All substances' tested indeed inhibit the enzyme to variable degrees, with a high inhibition by methoxyphenyl-N-acetylneuraminic acid, another sialidase substrate (fig. 3 ).

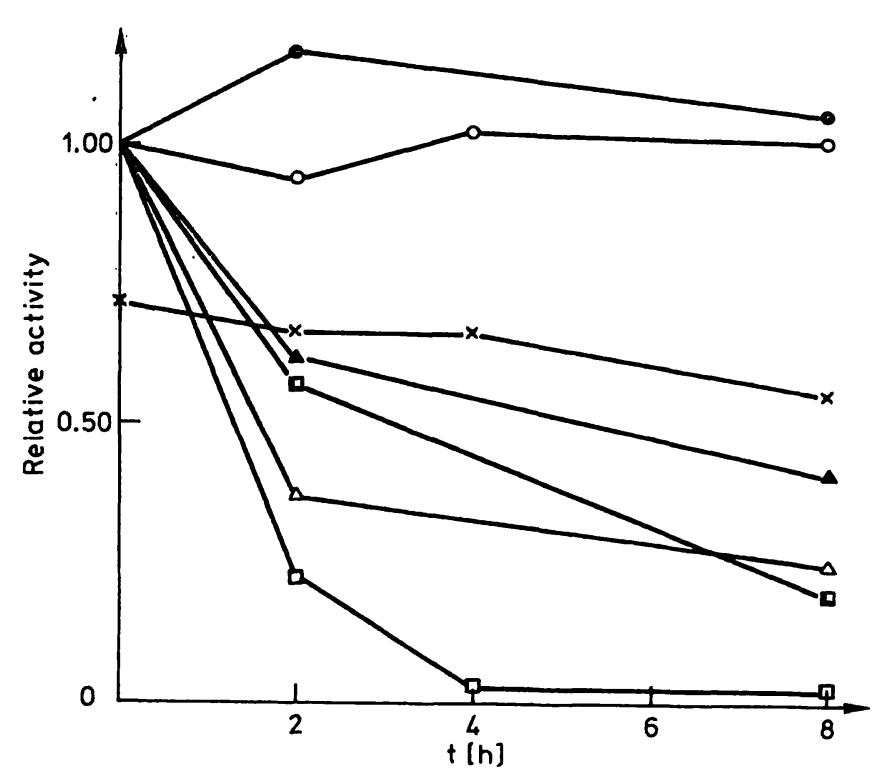

Fig. 2. Sialidase activity in the homogenate kept at different temperatures without and with albumin at a final concentration of $5 \mathrm{~g} /$ l.

O-O $0^{\circ} \mathrm{C}$, with albumin

$\mathrm{O}-\mathrm{O} 0^{\circ} \mathrm{C}$, without albumin

$\mathrm{x}-\mathrm{x} \quad 0^{\circ} \mathrm{C}, 6$ times frozen, without albumin

$\Delta-\Delta 23^{\circ} \mathrm{C}$, with albumin

$\triangle-\triangle 23^{\circ} \mathrm{C}$, without albumin

口- $37^{\circ} \mathrm{C}$, with albumin

$\square-\square 37^{\circ} \mathrm{C}$, without albumin

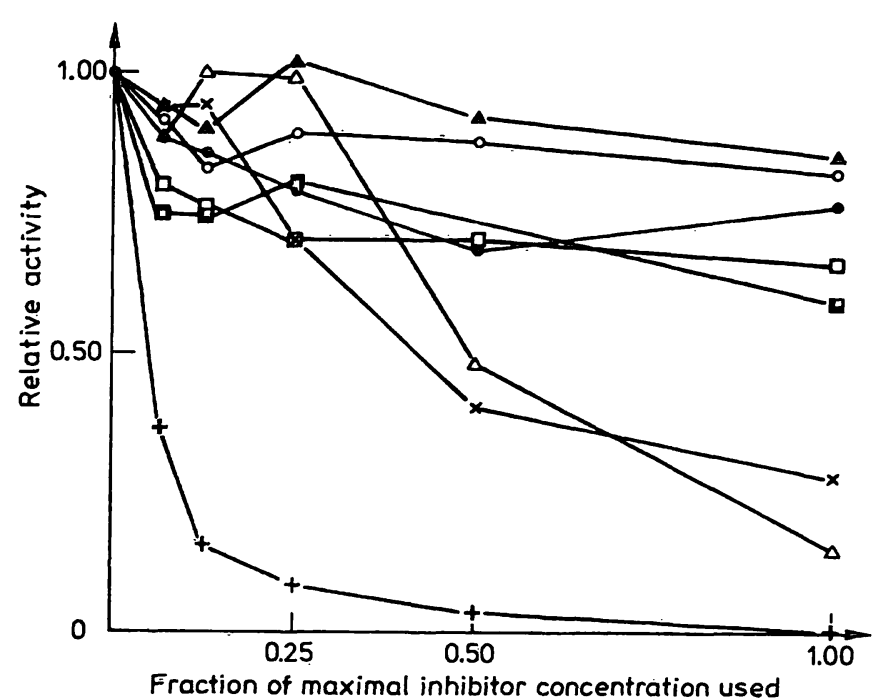

Fig. 3. Possible effectors were added to the incubation medium in different amounts and the catalytic activity of sialidase was measured at the respective effector concentrations.

Symbol Inhibitor

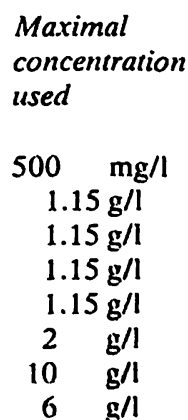




\section{Discussion}

The fluorimetric sialidase determination with this substrate was first introduced by Potier $(1,6,7)$ and in a previous paper we described the measurement of acid sialidase in cultured fibroblasts (8).

For the study of leukocyte sialidase, most authors have used leukocyte extracts made either by sonication or homogenization $(1,6-10)$. Since mechanical homogenization is an acceptable method for making leukocyte extracts with expression of the results per mg protein, we did not perform cell counts. For the isolation of the leukocytes, we have found that the catalytic activity of sialidase (per mg protein) is approximately $50 \%$ when dextran sedimentation of the leukocytes is used instead of simple sedimentation, but we have not further examined the reasons for this discrepancy. This observation however stresses the importance of using a standardized isolation procedure.

The use of intact leukocytes instead of homogenates has been advocated by Kuriyama et al. (11) because loss of activity can occur during homogenization. It is not understood at the present time whether substrate can either penetrate the lysosomes or if there is partial rupture of the lysosomal and cellular membrane in the incubation mixture with subsequent release of enzymes into the medium. In our hands, no diminished activity was observed when the pellet was homogenized during short periods at $0^{\circ} \mathrm{C}$. Intact leukocytes as well as homogenates lend themselves to sialidase determination as long as a strictly standardized procedure is followed for isolation and homogenization.

The $\mathrm{pH} 4$ optimum of the enzyme corresponds to that of a sedimentable leukocyte sialidase, which is also optimally active at this $\mathrm{pH}$ with sialyllactose as the substrate (12). Published $\mathrm{pH}$ optima using the same fluorescent substrate $(1,9)$ are very similar, although somewhat less acidic (between $\mathrm{pH} 4.2$ and 4.5). This acid $\mathrm{pH}$ optimum makes it reasonable to assume that the enzyme normally functions within lysosomes although this hypothesis has not been strictly proven.

The $K_{\mathrm{m}}$ value of $0.25 \mathrm{mmol} \cdot \mathrm{1}^{-1}$ is in very close agreement with the results of Potier (1) and Marchesani (9). Using labeled sialyloligosaccharides, sialidase has also been determined in leukocytes by $\mathrm{Ku}$ riyama et al. (11) and Strecker et al. (13) and $K_{m}$ values between 1.5 and $4.5 \mathrm{mmol} \cdot 1^{-1}$ were obtained $^{1}$ ). Owing to substrate scarcity, the initial sub-

\footnotetext{
1) Dependence of the $K_{m}$ value on substrate concentration is due to the fact that higher concentrations of methylumbelliferyl- $\mathrm{N}$ acetyl- $\alpha-D$-neuraminic acid inhibit the enzyme as we have found with other sialidases.
}

strate concentration used was about $0.1 \mathrm{mmol} \cdot \mathrm{1}^{-1}$. Since methylumbelliferyl- $\mathrm{N}$-acetyl- $\alpha-D$-neuraminic acid is now commercially available (Koch Light, Suffolk, England), we recommend final concentrations of $0.5 \mathrm{mmol} \cdot \mathrm{l}^{-1}$ (about twice the $K_{\mathrm{m}}$ value), thus avoiding substrate inbibition, high blank values and the high cost of substrate.

The observation of the gradual loss of enzyme activity when a blood sample was kept at room temperature makes it imperative to isolate leukocytes as soon as possible, preferably immediately after blood drawing.

On the other hand, the enzyme stability at $0^{\circ} \mathrm{C}$ contrasts with the fibroblast sialidase which looses most of its activity during the same period of time (8). Thus, it can be concluded that determinations done on leukocyte homogenates which have been kept in ice for some time are reliable. However, we have further observed that sialidase is inactivated when homogenates are kept at room temperature or $37^{\circ} \mathrm{C}$, while a few minutes at $50^{\circ} \mathrm{C}$ suffices to completely inactivate the enzyme. this inactivation can be partially prevented by adding albumin, as noted previously for fibroblast sialidase (8). In the routine test no addition is necessary, because the short incubation time allows the reaction to proceed linearly. On the basis of thermolability and other parameters, such as $\mathrm{pH}$ optimum and the effect of octyl- $\beta$-glucoside, two sialidase fractions have been described in human leukocytes (7).

Sialidase in intact leukocytes or homogenates is equally inactivated when kept at $-20^{\circ} \mathrm{C}$, although we have obtained some higher values for residual activity than previously reported (9), probably because we have thawed each homogenate only once at the time of enzyme determination. According to Suzuki et al. (10), normal leukocytes contain a freeze-labile and freeze-stable component. The latter amounts to approximately $25-35 \%$ of the total catalytic activity and would represent the remaining activity in adult patients with $\beta$-galactosidase-sialidase deficiency. We have reported previously on the deficiency of leukocyte acid sialidase in a patient with the cherry red spot myoclonus syndrome (8).

From figure 3 , it is clear that all substances tested indeed inhibit the enzyme to variable degrees. The inhibition by sialyllactose and by fetuin, in concentrations comparable to those used for colorimetric oligosaccharide or glycoprotein sialidase assays with the same substances, is only minimal. In contrast, methoxyphenyl- $\mathrm{N}$-acetylneuraminic acid (another sialidase substrate) is a potent inhibitor and has a remarkable effect even at low coricentrations. It is 
not unexpected that bovine submaxillary mucin and colominic acid are also inhibitory because they contain $\mathrm{N}$-acetylneuraminic acid, which is terminally linked $2^{\prime} \longrightarrow 6^{\prime}$ in the first compound and $2^{\prime} \longrightarrow 8^{\prime}$ in the latter homopolymer. The last substrate has also been used recently to investigate some characteristics of the enzyme (14). Except for methoxyphenyl-N-acetylneuraminic acid, Triton X-100 and sodium taurocholate have the highest inhibitory effect. Using the same substrate, a comparable inhibition by Triton X-100 was reported (9); other effectors, such as $\mathrm{CaCl}_{2}$ and $\mathrm{N}$-acetylneuraminic acid, have also been studied (1). With sialyllactose as substrate, the inhibitory effect of Triton X-100, deoxycholate and a series of chloride salts, has also been reported (12).

\section{References}

1. Potier, M., Mameli, L., Bélisle, M., Dallaire, L. \& Melançon, S. B. (1979) Anal. Biochem. 94, 287-296.

2. Warner, T. G. \& O'Brien, J. S. (1979) Biochemistry 18, 2783-2787.

3. Eschenfelder, V. (1979) Habilitationsschrift, Med. Fakultät, Universität Heidelberg.

4. Lowry, O. H., Rosebrough, N. J., Farr, A. L. \& Randall, R. J. (1951) J. Biol. Chem. 193, 265-272.

5. Den Tandt, W. R. \& Jaeken, J. (1981) Proc. Sixth Int. Sympos. Glycoconjugates. Tokyo September 1981 (Yamakawa, Y., Osawa, T. \& Handa, S., eds.), 464, Japan Scientific Societies Press, Tokyo.

6. Potier, M., Melạnçon, S. B., Dallaire, L., Chicoine, R., Mameli, L. \& Bélislè, M. (1979) Am. J. Med. Genet. 4, 191200.

7. Nguyen Hong, V. N., Beauregard, G., Potier, M., Bélisle, M., Mạmeli, L., Gatti, R. \& Durand, P. (1980) Biochim. Biophys. Acta $616,259-270$

\section{Conclusion}

The clinical determination of leukocyte sialidase is feasible if some precautions are taken. It is important that the leukocytes are isolated without delay after the blood drawing. Either fresh leukocytes in toto or dense extracts can be used. In the latter case, the homogenization time should be short, the homogenate dense and the procedure itself and subsequent handling of the homogenate done at $0{ }^{\circ} \mathrm{C}$ and incubation times should not exceed 30 minutes. No albumin addition is necessary, since substrate protection allows reaction linearity.

\section{Note added to proof}

According to Verheyen et al. (Abstracts of the Meeting of the European Study Group on Lysosomal Diseases, 1983), isolated lymphocytes should be used for the diagnosis of sialidosis and galactosialidosis.

8. Den Tandt, W. R. \& Leroy, J. (1980) Hum. Genet. 53, 383388.

9. Marchesani, S., Venerando, B., Fiorelli, A. \& Pretti, A. (1981) in Sialidases and Sialidosis. Proc. Int. Symp. Genoa September 1980 (Tettamanti, G., Durand, P. \& Di Donato, S., eds.), 191-203, Ermes, Milano.

10. Suzuki, Y., Sakuraba, H., Potier, M., Akagi, M., Sakri, M. \& Beppu, H. (1981) Hum. Genet. 58, 387-389.

11. Kuriyama, M., Someya, F., Miyataka, T. \& Koseki, M. (1981) Biochim. Biophys. Acta 662, 220-225.

12. Yeh, A. K., Tulsiani, D. R. P. \& Carubelli, R. (1971) J. Lab. Clin. Med. 78, 771-778.

13. Strecker, G., Michalski, J., Montreuil, J. \& Farriaux, J. P. (1976) Biomed. 25, 238-239.

14. Okada, S., Inui, K., Yataka, T. \& Yabuuchi, H. (1981) In: Sialidases and Sialidoses. Proc. Int. Symp. Genoa September 1980 (Tettamanti, G., Durand, P. \& Di Donato, S., eds.), 145-168, Ermes, Milano.

W. R. Den Tandt Medical Biochemistry Antwerp University Medical School B-2610 Wilrijk Belgium 
